\title{
Acute Graft-Versus-Host Disease: A Brief Review
}

\author{
Akut Graft Versus Host Hastalığl: Kısa Bir Derleme
}

\author{
(D) Elifcan Aladağ1, (D) Engin Kelkitli2, (D) Hakan Göker¹ \\ 1 Hacettepe University Faculty of Medicine, Department of Hematology, Ankara, Turkey \\ 2Ondokuz Mayıs University Faculty of Medicine, Department of Hematology, Samsun, Turkey
}

\section{Abstract}

Graft-versus-host disease (GvHD) is an important complication that can be observed after allogeneic hematopoietic stem cell transplantation (allo-HSCT). Acute GvHD (aGvHD) is seen after alloHSCT and the incidence of aGvHD is around 30\%-50\%. aGvHD prophylaxis is essential in patients undergoing allo-HSCT. Initial therapy for aGvHD is steroids. Prognosis is poor in aGvHD patients not responding to steroids. In this article, the pathobiology, clinical findings, prophylaxis, and treatment of aGvHD will be summarized.

Keywords: Graft-versus-host disease, Acute, Chronic

\section{Öz}

Akut graft-versus-host hastalığı (GvHD), allojeneik hematopoetik kök hücre nakli (alloHKHN) sonrasında görülebilen önemli bir komplikasyondur. Akut GvHD (aGvHD) insidansı yaklaşık \%30-50 oranında görülmektedir. AlloHKHN yapılan hastalarda GvHD proflaksisi önemlidir. aGvHD gelişen hastalarda başlangıç tedavisi steroiddir. Steroide yanıtsız aGvHD'de prognoz kötüdür. Bu yazıda aGvHD patobiyolojisi, klinik bulguları, profilaksisi ve tedavisi özetlenecektir.

Anahtar Sözcükler: Graft-versus-host hastalığı, Akut, Kronik

\section{Acute Graft-Versus-Host Disease (GvHD)}

Acute graft-versus-host disease (aGvHD) is seen after allogeneic hematopoietic stem cell transplantation (allo-HSCT) $[1,2,3,4]$. The incidence of aGvHD is around 30\%-50\% in HLA fully matched allo-HSCT [1]. aGvHD is also common in haploidentical and matched unrelated donor transplantation $[1,2]$.

\section{Pathobiology}

In 1966, Billingham detailed the biology of GvHD development as a three-stage process: a) the graft/donor should contain immunologically competent cells, b) the recipient/host must have tissue antigens not expressed in donor cells, and c) the recipient should be unable to mount an immune response to effectively eliminate the donor cells $[3,5]$. Hence, during alloHSCT, after conditioning the host, tissue antigens of the recipient are expressed to the donor T-cells, which leads to donor T-cell activation, expression, and enhanced immune response to the host; in other words, aGvHD occurs $[1,2,3,4]$. The mechanism underlying tissue damage in aGvHD is massive inflammatory cytokine secretion. Proinflammatory cytokines [tumor necrosis factor (TNF)- $\alpha$, interleukin (IL)- $1 \beta$, and IL-6] are seen, as well as the increased expression of the receptor repertoire (pattern recognition receptors) on antigen-presenting cells [6].

\section{Risk Factors}

The most important risk factor for aGvHD is HLA mismatch. Other risk factors include sex disparity between donor and recipient, the intensity of the conditioning regimen, increased age, multiparous female donors, ineffective GvHD prophylaxis, and the source of the graft. A study showed that aGvHD was significantly more common with total body irradiation involving a myeloablative regimen and peripheral stem cell transplantation from a fully matched related donor. In that study, the use of tacrolimus and methotrexate for GvHD prophylaxis was associated with a significant increase in GvHD risk compared to a cyclosporine-methotrexate combination [1].

\section{Clinical Manifestations}

GvHD can be acute or chronic based on the clinical presentation and its occurrence after or before 100 days after allo-HSCT. aGvHD may occur beyond this arbitrary cut-off of 100 days. The widely accepted National Institutes of Health consensus criteria have

๑Copyright 2020 by Turkish Society of Hematology

Turkish Journal of Hematology, Published by Galenos Publishing House 
been used to classify GvHD. GvHD is divided into four subclasses: 1) Classic aGvHD: Diagnostic and distinctive features of chronic GvHD (cGvHD) are absent. Clinical features of aGvHD and present within 100 days of allo-HSCT or donor lymphocyte infusion (DLI). 2) Persistent and/or recurrent late-onset aGvHD: Features of classic aGvHD without diagnostic manifestations of cGvHD occurring beyond 100 days after allo-HSCT or DLI. 3) Classic cGvHD: Present at any time after HSCT. Diagnostic and distinctive features of cGvHD are present without aGvHD. 4) Overlap syndrome: Features of both cGvHD and aGvHD can be seen $[4,7]$.

Clinically significant aGvHD may be cumbersome, affecting both morbidity and mortality $[1,2,3,4]$. The staging and grading of aGvHD can be seen in Table 1 [4]. The timely diagnosis of aGvHD is important. Hence, numerous novel biomarkers have been recently studied for timely diagnosis. These diagnostic and prognostic markers include systemic biomarkers (microRNAs, suppression of tumorigenicity 2), biomarkers of immune activation [TNF receptor 1, IL-7, B-cell activating factor (sBAFF)], and organ-specific biomarkers [REG3 $\alpha$ (regenerating islet-derived 3- $\alpha$ ], S100, TIM (T-cell immunoglobulin domain and mucin domain), cytokeratin-18, hepatocyte growth factor, and skin-derived anti-leukoproteinase, otherwise known as elafin). However, there is no specific GvHD biomarker in routine use [8].

\section{Prevention}

The most important step for the prevention of GvHD is minimizing risk factors with donor selection and a preparative regimen $[2,3,4]$. GvHD prophylaxis is essential for patients undergoing allo-HSCT [4]. Guidelines for GvHD prophylaxis have been proposed by the European Group for Blood and Marrow Transplantation and European LeukemiaNet [9].

The most common form of GvHD prophylaxis has been the combination of cyclosporine and a short course of methotrexate, which demonstrated improved survival compared to either drug alone. Both cyclosporine and tacrolimus decreased the proliferation of T-lymphocytes [4]. Tacrolimus plus methotrexate is better in decreasing the risk for aGvHD than the combination of cyclosporine and methotrexate, particularly in unrelated HSCT [10]. Both regimens are considered as cornerstones for most GvHD prevention strategies for patients receiving alloHSCT $[11,12]$. The effects of the addition of corticosteroids to the combination of cyclosporine and a short course of methotrexate have shown conflicting results $[13,14,15]$. Calcineurin inhibitors and methotrexate form the main backbone of prophylactic treatment.

\section{Treatment}

The choice of initial therapy for aGvHD depends on the organs involved, the severity of symptoms, and the prophylactic regimen used. Topical steroids are the most commonly used skindirected therapy for grade I aGvHD. Antihistamines may also be used. Bacigalupo et al. showed that steroid treatment of grade I GvHD prevents progression to grade II GvHD, but not to grade III-IV GvHD [16]. Initial therapy for grade II-IV aGvHD consists of high-dose glucocorticoid steroids. Steroid treatment is effective in approximately half of the patients; those with more severe aGvHD are less likely to respond. Treatment is usually started with the equivalent of 1-2 $\mathrm{mg} / \mathrm{kg} /$ day of prednisone and then tapered after a decrease in GvHD signs or symptoms. The transplantationrelated mortality rate is high in non-responders in the first 5

\begin{tabular}{|l|l|l|l|}
\hline Table 1. The clinical manifestation, staging, and grading of aGvHD. \\
\hline Organ & Clinical manifestation & Stage \\
\hline Skin & $\begin{array}{l}\text { Erythematous, maculopapular rash } \\
\text { involving palms and soles; may become } \\
\text { confluent } \\
\text { Severe disease: bullae }\end{array}$ & $\begin{array}{l}\text { Stage 1=<25\% rash } \\
\text { Stage 2=25\%-50\% rash } \\
\text { Stage 3=Generalized erythroderma } \\
\text { Stage 4=Bullae }\end{array}$ \\
\hline Gastrointestinal tract & $\begin{array}{l}\text { Nausea, vomiting, abdominal cramps, } \\
\text { diarrhea, ileus, distension, bleeding }\end{array}$ & $\begin{array}{l}\text { Stage 1=Diarrhea }>500 \mathrm{~mL} / \text { day } \\
\text { Stage 2=Diarrhea }>1000 \mathrm{~mL} / \text { day } \\
\text { Stage 3=Diarrhea }>1500 \mathrm{~mL} / \text { day } \\
\text { Stage 4=Ileus, bleeding }\end{array}$ \\
\hline Liver & Hyperbilirubinemia and increased alkaline & $\begin{array}{l}\text { Stage 1=Bilirubin 2-3 } \mathrm{mg} / \mathrm{dL} \\
\text { Stage 2=Bilirubin 3.1-6 } \mathrm{mg} / \mathrm{dL} \\
\text { Stage 3=Bilirubin } 6.1-15 \mathrm{mg} / \mathrm{dL} \\
\text { Stage 4=Bilirubin }>15 \mathrm{mg} / \mathrm{dL}\end{array}$ \\
\hline Grade & Skin & Gut & \\
\hline II & Stage 1-2 & 0 & Liver \\
\hline III & Stage 1-3 & 1 & and/or \\
\hline IV & Stage 2-3 & $2-4$ & and/or \\
\hline
\end{tabular}


days of steroid use. Several agents have been added to steroids in comparative studies but no evidence supports the use of these in combination for aGvHD therapy. The best complete response rate was obtained with mycophenolate in combination with other agents (etanercept, etc.) with steroids [17]. Recently the US Food and Drug Administration approved ruxolitinib, a JAK 1/2 inhibitor, and it has been used with considerable success in the treatment of steroid-refractory aGvHD [18].

Unfortunately, there is no standard indication or timing for the initiation of second-line therapy for aGvHD. Many agents have been tested alone or in combination with corticosteroids with limited sustained efficacy [4].

There are few guidelines in the literature regarding secondline cGvHD treatment. Extracorporeal photopheresis (ECP), mycophenolate mofetil, sirolimus, everolimus, rituximab, and ibrutinib are available options. ECP is recommended in the treatment of steroid-resistant aGvHD [19] and was found to result in overall response rates of 50\% to $65 \%$.

Table 2 provides a brief summary of some of the current novel second-line strategies for steroid-refractory aGvHD.

\section{Conclusion}

aGvHD leads to significant morbidity and mortality. Therefore, it is crucial to prevent its development. New therapy strategies for both prevention and treatment are needed. aGvHD is a leading cause of late morbidity and mortality. The standard treatment is steroid therapy and a calcineurin inhibitor may also be added. Further treatment strategies need to be developed for the treatment of aGvHD.

\section{Authorship Contributions}

Concept: E.A., E.K., H.G.; Design: E.A., E.K., H.G.; Data Collection or Processing: E.A., E.K., H.G.; Analysis or Interpretation: E.A., E.K., H.G.; Literature Search: E.A., E.K., H.G., Writing: E.A., E.K., H.G.

Conflict of Interest: No conflict of interest was declared by the authors.

Financial Disclosure: The authors declared that this study received no financial support.

\section{References}

1. Jagasia M, Arora M, Flowers ME, Chao NJ, McCarthy PL, Cutler CS, UrbanoIspizua A, Pavletic SZ, Haagenson MD, Zhang MJ, Antin JH, Bolwell BJ, Bredeson C, Cahn JY, Cairo M, Gale RP, Gupta V, Lee SJ, Litzow M, Weisdorf DJ, Horowitz MM, Hahn T. Risk factors for acute GVHD and survival after hematopoietic cell transplantation. Blood 2012;119:296-307.

2. Lee SE, Cho BS, Kim JH, Yoon JH, Shin SH, Yahng SA, Eom KS, Kim YJ, Kim HJ, Lee S, Min CK, Cho SG, Kim DW, Lee JW, Min WS, Park CW. Risk and prognostic factors for acute GVHD based on NIH consensus criteria. Bone Marrow Transplant 2013;48:587-592.

Table 2. Summary of some of the current novel second-line strategies.

Agent

Mycophenolate

mofetil

Sirolimus

|

Cyclophosphamide

Antithymocyte

globulin (ATG)

.

\section{Bortezomib}

etanercept
Comment

Refs.

A potent inhibitor of lymphocyte proliferation, and also frequently used in reduced intensity allo-HSCT.

Sirolimus is an immunosuppressant

$[21,22]$ that binds to FKBP12 and inhibits the mammalian target of the rapamycin inhibitor to block interleukin-2 (IL-2)-mediated signal transduction. In phase II trials, sirolimus was very effective in combination with tacrolimus [21]. A phase 3 prospective, randomized multicenter clinical trial showed that tacrolimus/sirolimus prophylaxis provided equivalent GvHD-free survival when compared with tacrolimus/methotrexate prophylaxis after matched related donor transplantation.

Cyclophosphamide alone or in combination with other immunosuppressive agents was administered in two doses for depletion of alloreactive conventional T-cells, which were highly induced immediately after transplant, and was shown to induce a relatively low incidence of GvHD even in haploidentical transplant recipients.

ATG has been associated with reduced GvHD but has also been discussed regarding effects on infection risk, relapse, and survival. While several randomized trials showed a significant benefit of ATG for the prophylaxis of GvHD, especially cGvHD, a metaanalysis from six randomized trials did not report improved overall survival or increased incidences of relapse and nonrelapse mortality.

Bortezomib is a proteasome inhibitor that has activity against multiple myeloma. A phase I/II trial demonstrated that it could be added to tacrolimus and methotrexate as aGvHD prophylaxis. This protocol is promising as the 6-month cumulative incidence of grade II-IV aGvHD was $13 \%$

Studies demonstrated elevated levels of TNF- $\alpha$ and IL- 1 in the serum of patients with aGvHD. Therapy of GvHD with humanized anti-TNF- $\alpha$ (infliximab) or human immunoglobulin $\mathrm{G} 1$ (etanercept) and IL-1 receptor antagonist (IL-1Ra) has shown some promise.

TNF: Tumor necrosis factor, IL: Interleukin, aGvHD: Acute graft-versus-host disease. 
3. Chao NJ. Graft-versus-host disease: the viewpoint from the donor T cell. Biol Blood Marrow Transplant 1997;3:1-10.

4. Goker H, Haznedaroglu IC, Chao NJ. Acute graft-vs-host disease: pathobiology and management. Exp Hematol 2001;29:259-277.

5. Billingham RE. The biology of graft-versus-host reactions. Harvey Lect 1966;62:21-78.

6. Toubai T, Mathewson ND, Magenau J, Reddy P. Danger signals and graftversus-host disease: current understanding and future perspectives. Front Immunol 2016;7:539.

7. Filipovich $A H$, Weisdorf $D$, Pavletic $S$, Socie $G$, Wingard JR, Lee SJ, Martin $P$, Chien J, Przepiorka D, Couriel D, Cowen EW, Dinndorf $P$, Farrell $A$, Hartzman R, Henslee-Downey J, Jacobsohn D, McDonald G, Mittleman B, Rizzo JD, Robinson M, Schubert M, Schultz K, Shulman H, Turner M, Vogelsang G, Flowers ME. National Institutes of Health consensus development project on criteria for clinical trials in chronic graft-versus-host disease: I. Diagnosis and staging working group report. Biol Blood Marrow Transplant 2005;11:945-956.

8. Ali AM, DiPersio JF, Schroeder MA. The role of biomarkers in the diagnosis and risk stratification of acute graft-versus-host disease: a systematic review. Biol Blood Marrow Transplant 2016;22:1552-1564.

9. Ruutu T, Gratwohl A, de Witte T, Afanasyev B, Apperley J, Bacigalupo A,

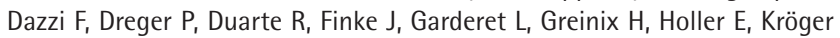
$N$, Lawitschka A, Mohty M, Nagler A, Passweg J, Ringdén O, Socié G, Sierra J, Sureda A, Wiktor-Jedrzejczak W, Madrigal A, Niederwieser D. Prophylaxis and treatment of GVHD: EBMT-ELN working group recommendations for a standardized practice. Bone Marrow Transplant 2014;49:168-173.

10. Ram R, Storb R. Pharmacologic prophylaxis regimens for acute graft-versushost disease: past, present and future. Leuk Lymphoma 2013;54:1591-1601.

11. Ratanatharathorn V, Nash RA, Przepiorka D, Devine SM, Klein JL, Weisdorf D, Fay JW, Nademanee A, Antin JH, Christiansen NP, van der Jagt R, Herzig RH, Litzow MR, Wolff SN, Longo WL, Petersen FB, Karanes C, Avalos B, Storb R, Buell DN, Maher RM, Fitzsimmons WE, Wingard JR. Phase Ill study comparing methotrexate and tacrolimus (prograf, FK506) with methotrexate and cyclosporine for graft-versus-host disease prophylaxis after HLA-identical sibling bone marrow transplantation. Blood 1998;92:2303-2314.

12. Nash RA, Antin JH, Karanes C, Fay JW, Avalos BR, Yeager AM, Przepiorka D, Davies S, Petersen FB, Bartels P, Buell D, Fitzsimmons W, Anasetti C, Storb R, Ratanatharathorn V. Phase 3 study comparing methotrexate and tacrolimus with methotrexate and cyclosporine for prophylaxis of acute graft-versushost disease after marrow transplantation from unrelated donors. Blood 2000;96:2062-2068.

13. Chao NJ, Schmidt GM, Niland JC, Amylon MD, Dagis AC, Long GD, Nademanee AP, Negrin RS, O'Donnell MR, Parker PM, Smith EP, Snyder DS, Stein AS, Wong RM, Blume KG, Forman SJ. Cyclosporine, methotrexate, and prednisone compared with cyclosporine and prednisone for prophylaxis of acute graft-versus-host disease. N Engl J Med 1993;329:1225-1230.

14. Hoyt R, Ritchie DS, Roberts AW, MacGregor L, Curtis DJ, Szer J, Grigg AP. Cyclosporin, methotrexate and prednisolone for graft-versus-host disease prophylaxis in allogeneic peripheral blood progenitor cell transplants. Bone Marrow Transplant 2008;41:651-658.

15. Chang $Y J, X u L P$, Wang $Y$, Zhang $X H$, Chen $H$, Chen $Y H$, Wang FR, Han $W$, Sun YQ, Yan CH, Tang FF, Mo XD, Liu KY, Huang XJ. Controlled, randomized, open-label trial of risk-stratified corticosteroid prevention of acute graftversus-host disease after haploidentical transplantation. J Clin Oncol 2016;34:1855-1863.

16. Bacigalupo A, Milone G, Cupri A, Severino A, Fagioli F, Berger M, Santarone S, Chiusolo P, Sica S, Mammoliti S, Sorasio R, Massi D, Van Lint MT, Raiola AM, Gualandi F, Selleri C, Sormani MP, Signori A, Risitano A, Bonifazi F; Gruppo Italiano Trapianto di Midollo Osseo (GITMO). Steroid treatment of acute graft-versus-host disease grade I: a randomized trial. Haematologica 2017;102:2125-2133.
17. Rashidi A, DiPersio JF, Sandmaier BM, Colditz GA, Weisdorf DJ. Steroids versus steroids plus additional agent in frontline treatment of acute graftversus-host disease: a systematic review and meta-analysis of randomized trials. Biol Blood Marrow Transplant 2016;22:1133-1137.

18. Zeiser R, Burchert A, Lengerke C, Verbeek M, Maas-Bauer K, Metzelder SK, Spoerl S, Ditschkowski M, Ecsedi M, Sockel K, Ayuk F, Ajib S, de Fontbrune FS, Na IK, Penter L, Holtick U, Wolf D, Schuler E, Meyer E, Apostolova $P$, Bertz $H$, Marks $R$, Lübbert $M$, Wäsch R, Scheid $C$, Stölzel F, Ordemann R, Bug $G$, Kobbe $G$, Negrin $R$, Brune $M$, Spyridonidis $A$, Schmitt-Gräff $A$, van der Velden W, Huls G, Mielke S, Grigoleit GU, Kuball J, Flynn R, Ihorst G, Du J, Blazar BR, Arnold R, Kröger N, Passweg J, Halter J, Socié G, Beelen D, Peschel C, Neubauer A, Finke J, Duyster J, von Bubnoff N. Ruxolitinib in corticosteroid-refractory graft-versus-host disease after allogeneic stem cell transplantation: a multicenter survey. Leukemia 2015;29:2062-2068.

19. Bredeson C, Rumble RB, Varela NP, Kuruvilla J, Kouroukis CT; Stem Cell Transplant Steering Committee. Extracorporeal photopheresis in the management of graft-versus-host disease. Curr Oncol 2014;21:e310-325.

20. McMurray RW, Harisdangkul V. Mycophenolate mofetil: selective T cell inhibition. Am J Med Sci 2002;323:194-196.

21. Alyea EP, Li S, Kim HT, Cutler C, Ho V, Soiffer RJ, Antin JH. Sirolimus, tacrolimus, and low-dose methotrexate as graft-versus-host disease prophylaxis in related and unrelated donor reduced-intensity conditioning allogeneic peripheral blood stem cell transplantation. Biol Blood Marrow Transplant 2008;14:920-926.

22. Cutler $C$, Logan $B$, Nakamura $R$, Johnston $L$, Choi $S$, Porter D, Hogan WJ, Pasquini M, MacMillan ML, Hsu JW, Waller EK, Grupp S, McCarthy P, Wu J, Hu ZH, Carter SL, Horowitz MM, Antin JH. Tacrolimus/sirolimus vs tacrolimus/methotrexate as GVHD prophylaxis after matched, related donor allogeneic HCT. Blood 2014;124:1372-1377.

23. Luznik $L$, Bolaños-Meade J, Zahurak $M$, Chen $A R$, Smith BD, Brodsky $R$, Huff CA, Borrello I, Matsui W, Powell JD, Kasamon Y, Goodman SN, Hess A, Levitsky HI, Ambinder RF, Jones RJ, Fuchs EJ. High-dose cyclophosphamide as single-agent, short-course prophylaxis of graft-versus-host disease. Blood 2010;115:3224-3230.

24. Ruggeri A, Labopin M, Bacigalupo A, Afanasyev B, Cornelissen JJ, Elmaagacli A, Itälä-Remes M, Blaise D, Meijer E, Koc Y, Milpied N, Schouten HC, Kroeger N, Mohty M, Nagler A. Post-transplant cyclophosphamide for graft-versushost disease prophylaxis in HLA matched sibling or matched unrelated donor transplant for patients with acute leukemia, on behalf of ALWPEBMT. J Hematol Oncol 2018;11:40.

25. Arai Y, Jo T, Matsui H, Kondo T, Takaori-Kondo A. Efficacy of antithymocyte globulin for allogeneic hematopoietic cell transplantation: a systematic review and meta-analysis. Leuk Lymphoma 2017;58:1840-1848.

26. Theurich S, Fischmann H, Shimabukuro-Vornhagen A, Chemnitz JM, Holtick U, Scheid C, Skoetz N, von Bergwelt-Baildon M. Polyclonal anti-thymocyte globulins for the prophylaxis of graft-versus-host disease after allogeneic stem cell or bone marrow transplantation in adults. Cochrane Database Syst Rev 2012:CD009159.

27. Koreth J, Stevenson KE, Kim HT, McDonough SM, Bindra B, Armand P, Ho VT, Cutler C, Blazar BR, Antin JH, Soiffer RJ, Ritz J, Alyea EP 3rd. Bortezomibbased graft-versus-host disease prophylaxis in HLA-mismatched unrelated donor transplantation. J Clin Oncol 2012;30:3202-3208.

28. Cullup H, Dickinson AM, Jackson GH, Taylor PR, Cavet J, Middleton PG. Donor interleukin 1 receptor antagonist genotype associated with acute graft-versus-host disease in human leucocyte antigen-matched sibling allogeneic transplants. Br J Haematol 2001;113:807-813.

29. Levine JE, Paczesny S, Mineishi S, Braun T, Choi SW, Hutchinson RJ, Jones D, Khaled Y, Kitko CL, Bickley D, Krijanovski O, Reddy P, Yanik G, Ferrara JL. Etanercept plus methylprednisolone as initial therapy for acute graftversus-host disease. Blood 2008;111:2470-2475. 